The following have been elected members of the Academy : E. Anderson, professor of botany, Washington University, St. Louis; H. W. Babcock, astronomer, Mount Wilson Observatory, Pasadena; E. C. Bain, vice-president in charge of research and technology, United States Steel Corporation, Pittsburgh; A. K. Balls, professor of enzyme chemistry, Purdue University ; J. Bardeen, professor of physics and electrical engineering, University of Illinois; W. Bloom, professor of anatomy, University of Chicago ; M. N. Bramlette, geologist, Scripps Institution of Oceanography, La Jolla; W. R. Brode, associate director, National Buresu of Standards, Washington, D.C. ; M. Calvin, professor of chemistry, University of California, Berkeley; B. Chance, director of the Johnson Foundation, University of Pennsylvania; R. P. Feynman, professor of theoretical physics, California Institute of Technology, Pasadena; H. O. L. Fischer, professor of biochemistry, University of California, Berkeley ; J. B. Fisk, director of research in the physical sciences, Bell Telephone Laboratories, Murray Hill, N.J. ; J. P. Guilford, professor of psychology, University of Southern California, Los Angeles; N. Jacobson, professor of mathematics, Yale University ; G. E. Kimball, professor of chemistry, Columbia University; W. E. Lamb, professor of physics, Stanford University; E. M. Landis, professor of physiology, Harvard Medical School; E. Mayr, professor of zoology, Harvard University; W. F. Meggers, chief of the Spectroscopy Section, National Bureau of Standards, Washington, D.C.; A. E. Mirsky, member of the Rockefeller Institute for Medical Research, New York ; B. O'Brien, vice-president, American Optical Company, Southbridge, Mass.; W. K. H. Panofsky, professor of physics, Stanford University; A. Petrunkevitch, professor emeritus of zoology, Yale University; A. R. Rich, professor of pathology, School of Medicine, Johns Hopkins University; J. H. Steward, professor of anthropology, University of Illinois ; E. H. Vestine, chairman of the Section on Statistical and Analytical Geophysics, Department of Terrestrial Magnetism, Carnegie Institution of Washington; F. H. Westheimer, professor of chemistry, University of Chicago; R. H. Wetmore, professor of botany, Harvard University; A. E. Whitford, professor and director, Washburn Observatory, University of Wisconsin.

The following have been elected foreign associates of the Academy : Sir Macfarlane Burnet, director of the Walter and Eliza Hall Institute for Medical Research, Melbourne; Albert M. G. R. Portevin, consulting engineer, Paris; and Otto Renner, professor and head of the Botanical Institute and Garden, Munich.

\section{REACTIONS OF THE HUMAN BODY TO INJURY}

$\mathrm{T}$

HE British Council has done good service to the serious student of disease by bringing together* a number of articles which show very clearly the changing attitude to injury reactions. No longer can this topic be considered as the sole province of pathology. Indeed, it is all too clear that no progress need be expected unless the attack be planned on the widest possible front. The chemist and physicist,

*British Medical Bulletin, 10, No. 1 (1954). Pp. 72. (Medical British Medical Bulletin, 10, No. 1 (1954). Pp. ${ }^{72 .}$ (
Dept., British Council, 65 Davies Street, London, W.1.) the clinician, bacteriologist and pathologist must each play his part in the study of what goes on in the injured tissues and of the factors that modify the responses until death or recovery occurs. This re-birth of the old doctrine of inter-relationship between constitutional factors and local tissue response owes a great deal to Sir Edward Mellanby, until lately secretary of the Medical Research Council and himself an original investigator in the field, and it was a felicitous thought to persuade him to write the introduction to the British Council's symosium.

Prof. G. Payling Wright tells a fascinating story about tetanus which is largely the outcome of his own recent work. Ingenious experiments have shown how the toxin of this unpleasant germ reaches the central nervous system and exerts its effects at the synapses of the spinal cord. Prof. Wright indicates how infection may be prevented and pleads for general immunization of the young.

Under the title of "Gas Gangrene", Prof. C. L. Oakley reviews the present-day knowledge of anaerobic infections. His masterly exposition of their genesis shows that changes in oxidative reduction potentials, $p H$ requirements and various other disturbances in damaged muscle provide ideal conditions for the nourishment and growth of anaerobic bacteria. The various toxins manufactured by these organisms are characterized so far as that is possible and their modes of action discussed. In this way precision replaces empiricism in the investigation and treatment of these diseases.

Dr. J. B. Cavanagh and Prof. R. H. S. Thompson provide much food for thought in their brief but admirable review of demyelination. They conclude that several dissimilar processes, which range from deficiency states to anti-cholinesterases, have this common feature. The results of their further study will be awaited with interest, since it is likely that here again the enzymic factors will provide the clue.

An unusual article comes from Drs. J. D. Judah and W. G. Spector, who apply modern enzymological techniques to the diseased cell. Much of this information is derived from the authors' original work on poisons such as dinitrophenol and carbon tetrachloride, and it would seem that we are on the way to resolving the problem of some cell injuries in terms of biochemical disturbance. This, too, is the main theme of Dr. H. Cullumbine's paper on war gases, some of which interfere with enzyme systems and so lead to permeability changes in the endothelium of blood vessels and upset fluid equilibrium in the body. The latter subject is well discussed by Dr. F. C. Courtice, who defines the role of altered lymph flow from damaged tissues and assesses its connexion with hæmodynamics and osmotic properties of the blood. Dr. Courtice's point of view recalls the stimulating attack made about fifty years ago by the late Prof. E. H. Starling, and possesses the special merit of being based on his own superb technique for the measurement of lymph flow.

No compilation on injury can neglect the subject of 'shock', and in this symposium full justice is done to various aspects of this elusive problem. Prof. H. N. Green and Dr. H. B. Stoner describe their stimulating hypothesis, which links shock with carbohydrate metabolism; Dr. R. T. Grant summarizes his notable clinical studies made during the Second World War and Dr. J. P. Bull draws upon his wide experience in a helpful article on burns. Shock naturally raises the question of blood transfusions, and Dr. R. Bodley Scott deals with the 
clinical aspect, while a band of workers, Sir Alan Drury, Dr. P. L. Mollison, Dr. W. d'A. Maycock and Dr. Margaret E. Mackay, review the problems of blood storage, plasma and its substitutes.

Finally, Dr. W. Ritchie Russell discusses head injuries, with an admirable blend of physiology and surgery which is a model of clinical investigation.

Each of these articles is well documented and makes good reading, since a leading principle is kept well to the fore even when information is scanty and apparently contradictory.

The scientific editor, Dr. W. G. Spector, is to be congratulated on the success of his efforts.

V. UDALI

\section{WORKABLE PEAT RESOURCES OF SCOTLAND}

$\mathrm{W}$ ORKABLE deposits of peat, equivalent in value as fuel to twenty years output of coal, or 500 million tons, are estimated to be available in Scotland as the result of a painstaking inquiry carried out by the Scottish Peat Committee, which had been set up in 1949 and reported in 1953*. This accessible reserve occupies a total area of $1,625,000$ acres, covered to a depth of $2 \mathrm{ft}$. of peat, and contains a thousand million tons of solid fuel, some 600 million tons consisting of mosses of which the depth, accessibility and other features make them suitable for utilization. In the associated inquiries into the winning and utilization of the peat, the Committee kept prominently in mind the prospect that ultimately much of the land now under peat might be reclaimed for agriculture or forestry.

In a number of European countries, perhaps more richly blessed by reserves of peat than is Scotland, peat production has been developed on a considerable scale, and mechanical methods of winning fuel have been well advanced. The various methods available were examined by the Committee. Thus, peat produced by automatic plants, with excavators, macerators and spreaders for drying, is likely to be more expensive than coal in Britain unless smaller types of machines can be made to reduce costs substantially.

Hydro-peat - that is, raw peat disintegrated into a slurry by a high-powered water-jet, pumped from the bog to a drying field and cut into blocks-might have some application if a cheap method of removing water could be devised; but the Committee considers that this is not yet practicable. In the production of milled peat a horizontal cut of about $\frac{1}{2}$ in. thickness is made, the machine operating on the same principle as a motor grass-mower. The milled peat, after preliminary drying in situ and harvesting, is taken to a drying and briquetting plant. The product has a net calorific value of 8,000 B.Th.U. per lb., and is relatively dense and transportable. The process requires fairly favourable climatic conditions for drying, and, accordingly, in Scotland the number of harvests might be limited to some $18-20$ in a season. The cost is roughly competitive with coal as delivered to power stations in the north of Scotland.

The technical problem of greatest difficulty is to find an efficient and economical means of reducing the moisture content of peat from upwards of 90 per

* Scottish Home Department. Report of the Scottish Peat Committee. I'p. $66+8$ plates. (London: H.M.S.O., 1954.) 5s. net. cent in the raw state to a level at which it can be burned. Nearly all processes now operating commercially rely on wind and sun to do so. This makes peat production a seasonal operation with expensive seasonal labour. The application of mechanical presses was investigated, but it was found that their suitability has not reached a scale at which their commercial use could be recommended for Scottish conditions. Other processes considered include wetcarbonizing, de-watering by centrifuge and electroosmosis; but they were all found to be less promising than pressure de-watering. There may, however, be scope for developing some other uses of peat in association with a fuel and power plant-for example, the production of moss litter, or the extraction of waxes. Other processes, such as carbonization, hydrogenation and use as a building material, are considered less hopeful.

Perhaps the most interesting and novel feature of these pioneering efforts has been the application of peat firing to the gas turbine used as a power generator. The attractive features of the gas turbine are the greater flexibility in siting, less demand for cooling water, reduced possibility of damage by abrasion from harmful constituents of its low content of ash, and greater possibilities of more efficient use of the potential heat of the fuel. Thus it may be possible to dry a wet fuel like peat from a higher moisture content by the uso of the waste heat available.

The closed-cycle gas turbine has been investigated by the Scotland Hydro-Electric Board. A description is given in the present report of trials with a machine of this type, of some 500 H.P. capacity, in which a flue-gas drier was incorporated to dry peat from a moisture content of $50-55$ per cent to a moisture content of 30 per cent, thus enabling it to operate with milled peat or with any of the accepted methods of peat production involving air-drying.

Another gas turbine, of $750 \mathrm{~kW}$. capacity, operating on the open cycle, has bcen sponsored by the Ministry of Fuel and Power and is already in limited production, and regarded as having reached a stage of proved reliability. A rotary louvre drum drier has been ordered and should give valuable information for application to both the open- and the closed-cycle systems. It is estimated that a small peat-burning closed-cycle gas turbine of $2,000 \mathrm{~kW}$. might produce power at a cost comparable with small diesel stations of similar output, but the cost would be much higher than that of power from large hydro-electric schemes. On the other hand, once a large peat-fired plant can be developed, the Committee considers that important. economies could result which would enable such a plant to produce power at a cost comparable with large coal-fired steam turbines. Since the report was drafted the Hydro-Electric Board and the Central Electricity Authority have agreed, with assistance from the Government Development Fund, to contribute towards the capital cost of establishing a 2,000-kW. peat-burning unit at Altnabreac, Caithness. Meanwhile, investigations are to go ahead on pressure de-watering and other methods of peat production. An open-cycle machine of $750 \mathrm{~kW}$. and a large press ordered by the Ministry of Fuel and Power are to be included in the developments at the same station. Thus Britain has taken the lead in developing solidfuel gas turbines. Further, the peat experiments foreshadowed in the report will be watched with great interest in a number of other countries, particularly Ireland, Sweden and Canada. 